Cahiers $d u$ MONDE RUSSE

\section{Cahiers du monde russe}

Russie - Empire russe - Union soviétique et États indépendants

$47 / 4 \mid 2006$

Varia

\title{
Marlène Laruelle, Mythe aryen et rêve impérial dans la Russie du XIX ${ }^{\mathrm{e}}$ siècle
}

David Schimmelpenninck van der Oye

\section{OpenEdition \\ Journals}

\section{Electronic version}

URL: https://journals.openedition.org/monderusse/6783

DOI: 10.4000/monderusse. 6783

ISSN: $1777-5388$

\section{Publisher}

Éditions de l'EHESS

\section{Printed version}

Date of publication: 30 December 2006

Number of pages: 913-914

ISBN: 978-2-7132-2098-2

ISSN: $1252-6576$

\section{Electronic reference}

David Schimmelpenninck van der Oye, "Marlène Laruelle, Mythe aryen et rêve impérial dans la Russie du xix siècle", Cahiers du monde russe [Online], 47/4 | 2006, Online since 03 July 2009, connection on 03 September 2022. URL: http://journals.openedition.org/monderusse/6783 ; DOI: https://doi.org/ 10.4000/monderusse.6783

This text was automatically generated on 3 September 2022

All rights reserved 


\title{
Marlène Laruelle, Mythe aryen et rêve impérial dans la Russie du $\mathrm{XIX}^{\mathrm{e}}$ siècle
}

\author{
David Schimmelpenninck van der Oye
}

\section{REFERENCES}

Marlène LARUELLE, Mythe aryen et rêve impérial dans la Russie du XIX $x^{e}$ siècle.

Paris : CNRS, 2005, $223 \mathrm{p}$.

1 What is the intellectual genealogy of Eurasianism, the notion that Russia is separate from Europe and Asia yet combines elements from both continents? This is the question Marlène Laruelle, a prolific young French scholar of Russian national identity, currently at the Woodrow Wilson Center in Washington, considers in her provocative new book, Mythe aryen et rêve impérial dans la Russie du XIX ${ }^{e}$ siècle. Laruelle's curiosity was piqued as she wrote an earlier work, L'idéologie eurasiste russe ou comment penser l'empire (Paris: L'Harmattan, 1999). She had initially expected to find the answer among some nineteenth-century "Asianist" precursors of the early twentieth-century émigré Eurasianists, who likewise might have looked to the East as a source of their cultural heritage. But the matter proved to be more complicated.

In reconstructing pre-Revolutionary Russian thinking about their continental identity, Laruelle argues that before the Eurasianists virtually no one denied their nation's fundamental European origins. While Asia did play a role, this was in the context of an Indo-Iranian "Aryan" ancestry in the distant past. The influence of German and other Western Romanticism is clear. Aryanism first appeared as a result of the discoveries by such eighteenth-century philologists as Sir William "Oriental" Jones about the striking similarities between ancient northern Indian Sanskrit and many modern European languages. In its most notorious form, "Aryanism" was transformed by the likes of the comte de Gobineau, Houston Stewart Chamberlain and Alfred Rosenberg from a 
linguistic theory into a murderous ideology of racial superiority. The Russian variant, Laruelle emphasizes, remained firmly based in its more gentle Romantic roots. For Russians, "to talk about race makes no sense. They are Christians who speak a Slavic language, and these are the only things that count" (p. 38).

Laruelle argues that Aryanism arose in Russia to rebut French and German ideas about the former as "Turanian," or Asiatic Turco-Mongol nomads. The Russian rejoinder was to trace its origins to Scythians, who were much closer to the Indo-Iranian Aryan "cradle." According to Laruelle, "the Russian response is in effect an inverted mirror image of the Western discourse: Whereas Germans trace a direct line to India, Russians see a similar continuity with Scythia..." (p. 47). In this way, Russia's proximity to Asia paradoxically gave it a stronger claim to being European than its Western neighbours. In an intriguing final chapter, Laruelle suggests that Aryanism eventually became more than a defensive affirmation of Russia's place in Europe, and also evolved into a summons to eastward imperial conquest. Much as some Victorian thinkers justified British rule in India by virtue of a putative Aryan solidarity with the Brahmin caste, Fedor Dostoevskii, Nikolai Przheval'skii, Prince Esper Ukhtomskii, and other champions of tsarist expansion in Asia similarly based their reasoning on a "return to the source."

Laruelle's Mythe aryen... is an important contribution to Russian intellectual history. Its greatest virtue lies in its consideration of the Asian component. If there is a long and extensive literature about Russia's affinity with the West, aside from some studies of Eurasianism the equally ambiguous relationship with the East has been largely neglected. While perhaps overly categorical in rejecting any pre-Eurasianist notions about a "Turanian" heritage, it is a work of remarkable erudition. I eagerly await Laruelle's next book. 